\title{
The state of Early Linear Pottery Culture research in Slovakia
}

\author{
Noémi Beljak Pažinová, Tatiana Daráková \\ Department of Archaeology, Constantine the Philosopher University in Nitra, Nitra, SK \\ nbpazinova@ukf.sk, tanadarakova@gmail.com
}

\begin{abstract}
The article focuses on the current state of research of the first Neolithic culture in Slovakia. So far around 70 sites are known from Slovakia dated to the Early Linear Pottery Culture and the Early Eastern Linear Pottery Culture. Most of the sites are known only from surface collections, and in only four cases have dwellings been documented. Settlement features/pits have been discovered at around half the sites. Finally, we know graves from only four (and possibly five) sites. In the article we deal also with the elaboration of the Early LPC/ELPC material culture. We discuss pottery from the point of view of typology and decoration and other types of findings, such as chipped stone industry, ground and polished stones, small clay artefacts, daub, animal bones etc., are not omitted either. The goal is to evaluate the research possibilities of the Early LPC/ELPC in Slovakia.
\end{abstract}

KEY WORDS - Slovakia; Early Linear Pottery culture; settlement; material culture; current state

\section{Stanje raziskav zgodnje kulture linearno trakaste keramike na Slovaškem}

IZVLEČEK - V članku se osredotočava na trenutno stanje raziskav prve neolitske kulture na Slovaškem. Do danes poznamo 70 slovaških najdišč, ki datirajo v čas zgodnje kulture linearno trakaste keramike in zgodnje vzhodne kulture linearne keramike. Večina najdišč predstavlja površinske najdbe in le na štirih najdiščih so bili odkriti sledovi domovanj. Naselbinske strukture/jame so bile dokumentirane na približno polovici najdišč. Grobove poznamo iz štirih, morda petih najdišč. V članku predstavljava tudi obdelavo materialne kulture zgodnje LTK in vzhodne LTK. Lončenino predstavljava iz vidika tipologije in okrasa, pri čemer ne zanemarjava tudi druge vrste najdb, kot so kamnita orodja, polirani kamni, majhni keramični predmeti, hišni lep, živalske kosti itd. Cilj preiskave je oceniti raziskovalni potencial zgodnje LTK in vzhodne LTK na Slovaškem.

KLJUČNE BESEDE - Slovaška; zgodnja kultura linearno trakaste keramike; naselbina; materialna kultura; trenutno stanje

\section{Introduction}

Linear Pottery Culture (hereinafter LPC) represents the oldest known culture of the Neolithic in the territory of Slovakia. It is the period of first Neolithic societies and a new form of cultural expression. The Neolithic in Central Europe is dated to the period between the middle of the $6^{\text {th }}$ and the second half of the $5^{\text {th }}$ millennia, and in many regions it is associated with first farmers. The LPC is characterized main- ly by a homogenous style of pottery shapes and decoration. The region of the Middle Danube is considered to be the primary region of the LPC around $5500 / 5400 \mathrm{cal} \mathrm{BC}$, when its formative phase started. Development of the LPC in the territory of Slovakia as well as in the whole of Europe can be divided on the basis of regional differences and diversity of the terrain - into the western LPC spread in south- 
western Slovakia following from the settlement in the northern part of Transdanubia and/or in Lower Austria and the Eastern Linear Pottery culture (hereinafter ELPC) in eastern Slovakia, which is part of the Alföld Linear Pottery culture (hereinafter ALPC) formed in the Upper Tisza region in the second quarter of the $6^{\text {th }}$ millennium $\mathrm{BC}$.

The genesis of the Early LPC is not unambiguous. On one hand, there are opinions which see its origin under influence of the Vinča culture from the Starčevo culture primarily south of Balaton Lake in Transdanubia (e.g., Pavlù 2012.95; Bánffy 2004; Bánffy, Oross 2009.223-224, 227, Tab. I; Marton, Oross 2012.233-236) or in the wider region of Transdanubia, western parts of Austria (primarily Lower Austria), and southwestern Slovakia (Lenneis 2010. 190-193). On the other hand, there is an opinion that the Early LPC started as early as the Starčevo culture in the territory north of the Starčevo settlements along the Danube as far as southwestern Slovakia, not in Transdanubia south of Balaton Lake (Pavúk 2014.199-207, Map 3; Pavúk, Farkaš 2013).

The greatest interest of investigators in the Early LPC/ELPC in the territory of Slovakia was in the 1970s and 1980s, and since then less and less attention has been paid to the culture, except for the Moravany site in the Eastern Slovak Lowland. In the article we thus deal with previously published information from domestic as well as foreign literature. Unprocessed and previously unpublished material or information passed orally was not included in the data. Mostly, brief reports occur in works informing the occurrence of finds during surface collections or rescue excavations. There are no summarizing publications (except for the Early ELPC site Moravany) about sites with long-term research (e.g., sites Zemplínske Kopčany, Košice, Senica). The fact that most finds were obtained from multicultural sites with dominant material from other cultures is also a determining factor in identification of the Early LPC/ELPC culture. In such cases, often only a notice of occurrence of this culture is found in the literature, without any further information.

\section{Research history}

Although the period of the Late Stone Age in Slovakia first attracted attention as early as the $19^{\text {th }}$ century, almost no records have been preserved from those first - often amateur - researches (for more information see, e.g., Pavúk, Šiška 1971.320). The first systematic review of prehistoric periods includ- ing cultures from the Neolithic and Aeneolithic in Slovakia was published by Jan Eisner (1933) between the world wars. It presents nine sites belonging to the LPC- Gajary, Devínska Nová Ves, Čeklís, Gocnod, Hurbanovo, Zeleneč, Borovce, Stráne, and Moravany (Eisner 1933.14-15). Later, Vojtech Budinský-Krička (1947) published a work called Slovakia in the Late Stone Age (in Slovak: Slovensko v mladšej dobe kamennej), where he included Bešeňová, Blesovce, Behynce, Lúky, Gergel'ová, Gocnod, Zeleneč, Gajary among LPC sites (Budinsky-Krička 1947.56).

The new ELPC sites of Lúčky, Oreské, Kapušany, Cejkov, Michalovce, and Košice-Barca were discovered by surveys in eastern Slovakia in the 1950s (Andel 1955.148, 150; Hájek 1957). The first destructive research was carried out in 1951 at the site of Košice-Barca III, where a settlement of the Bükk culture (Middle Neolithic) was studied; eight features with exclusively Linear Pottery finds were also uncovered. Unfortunately, only incomplete pottery data without division by features was published from the site (Šiška 1989.12).

It was only after the discovery of Barca III type in eastern Slovakia that interest in study of the Alföld pottery increased, since similarities in their shapes and decorations were obvious (Pavúk, Šiška 1971. 322). The Linear Pottery from eastern Slovakia, which follows from the pottery of Barca III type, also corresponds with finds of the Alföld pottery. The difference in names is only due to geographical reasons (Točik 1970.74).

The Michalovce-Hrádok site, where seven features were studied in 1954, is important because the collection of finds comprised material from the older phase of ELPC and sherds of protolinear character and from the younger phase of ELPC (Šiška 1989. 15). Fragmentary material of the Early ELPC was discovered in the 1950s at the sites of Lúčky and Zemplínske Kopčany (Pavúk, Šiška 1971.327; Vizdal, Paulik 1959). On the basis of results of these investigations, Kopčany was indicated as a regional group within the older phase of ELPC in the Eastern Slovak Lowland (Šiška 1989.67).

Several new investigations were carried out in the western part of Slovakia at Early LPC sites in Hurbanovo (Pavol Čaplovič in 1956), Vel'ký Grob (Bohuslav Chropovský in 1986), Čachtice (Titus Kolník and Jozef Paulík in 1959) and, e.g., Milanovce (Juraj Pavúk in 1961). Such research considerably extended 
our knowledge of the culture. The first summarizing study about the Early LPC in Slovakia or its relative chronology was elaborated by Pavúk (1962; 1980. 11).

In the eastern part of Slovakia, the sites of Vel'ké Raškovce, Hutniky, Valaliky, Komárovce, Blažice and Košice-Barca, Svetlá III (Bánesz, Lichardus 1969.204207) and Čečejovce (Šiška 1989.15) were added to the list of the Early ELPC sites. In 1975-1976, research continued in Košice-Barca (Budinsky-Krička 1976.46-54), Bara (Šiška 1989.148), Čečejovce ( $\check{C} a$ plovič et al. 1978.62-70), Vel'ké Trakany (Šiška 1989.170) as well as the rescue excavations in Žbince (Šiška 1989.178). The first study on ELPC was published by Karol Andel (1955), and then others by Jan Lichardus $(1986 ; 1970 ; 1972)$ and in more detail by Stanislav Šiška $(1982 ; 1989)$ and Marián Vizdal (1997a; 1997b).

In western Slovakia, rescue excavations were carried out in the 1970s at the sites of Krakovany (Sedlák 1975.98), Nevidzany (Bátora 1976.25-26), Čataj (Pavúk 1976.177-182), Blatné (Pavúk 1978.192195), Komjatice (Toč ‘k 1978.246-272), or Cífer-Pác (Kolnik 1980a.142-155; 1980b.106-111); they successfully enriched the previously known finds from the Early LPC.

Since 1980, destructive research continued in eastern Slovakia in the Košice basin at the sites of Čečejovce (Šiška 1981.236-289) and Vel'ké Raškovce (Bánesz 1981.23-26). In Malé Raškovce (Vizdal 1988.140-141), only a surface collection was carried out with a positive result for the Early ELPC. Rescue excavations were carried out at three new sites - Čel'ovce (Vizdal 1986.141), Slavkovce (Vizdal 1990. 69-170) and Zbudza (Vizdal 1986.237-238). The results of the rescue excavations at Košice-Červený rak site in 1980 are important; there, protolinear pottery and the middle Neolithic Tiszadob Group pottery was identified (Kaminská et al. 2008.83). Finds from the Košice, Galgovec site (Kaminska 1998), Slavkovce (Vizdal 1996.187-188; Skiba et al. 1996), Zalužice (Vizdal 1996.186-187) and Ždaňa (Béreš 1996) were added by the end of the previous century from eastern Slovakia. Also important is the site of Slavkovce, where the presence of the oldest Neolithic population in eastern Slovakia (the Szatmár Group) was found (Vizdal 1997a.50).

New sites were also found in the last decades of the $20^{\text {th }}$ century in western Slovakia. Surface collections and rescue excavations extended the number of known sites with the Early LPC by $e . g$., Borovce (Staššiková-Štukovská 1988.173-190), Kátov (Drahošová 1987.39-40), Bratislava, Mlynská ulica street (Egyházy-Jurovská, Farkaš 1987.41), Bernolákovo (Farkaš 1987.42), Slovenský Grob (Marková 1988. 89). New finds were obtained in the districts of $\mathrm{Tr}$ nava, Senica, Nové Zámky and Nitra, however, surface excavations or accidental finds prevailed. Several features with material were uncovered in Senec (Farkaš 1995.5-22) or in Mojzesovo (Ruttkay 1997. 140). Material of the Early LPC was first found in the southern part of central Slovakia in Tornal'a, formerly called Šafárikovo (Kovács 1984.45), Bátka (Kovács 1982.165-168) and in the central Gran (Hron) river basin in Ladomerská Vieska (Mosný, Šiška 1997). While the first two sites can be attributed to the ELPC, Ladomerská Vieska can be considered as the northernmost site of the Early LPC in Slovakia and classified in the Bíña phase.

Since the turn of the century, only the site of Moravany was systematically studied in eastern Slovakia (e.g., Kaczanowska et al. 2003; Kalicki et al. 2004. 95; 2005; Koztowski et al. 2003). Material from the ELPC was detected as part of surveys in Kendice (Horváthová 2017), Zemplín (Horváthová, Hreha 2017) and in Vel'ký Šariš (Vizdal, Derfiñák 2006); however, most of the finds can be classified as part of the middle Neolithic Tiszadob Group.

In the western part of Slovakia, surface surveys detected new sites in Kozárovce (Ivanič 2002.79-80) and Choč (Bielich 2004.34), while accidental finds contributed to our knowledge of Borovce (Verčik 2002.224), Dolné Krškany (Ruttkayová 2004.161), and Stupava (Farkaš 2012.7-12). Several new features were also found in Senica-Sotina (Farkaš 2008. 57-58) and Hurbanovo-Bohatá (Březinová, Pažinová 2011.100).

\section{Chronology of the Early LPC/ELPC in Slovakia (Table 1)}

The relative chronology of the Early LPC in Slovakia is first of all defined by different features and decoration of the surface of vessels. Quality data or stratified finds have been absent for a long time. The first classification of material from the Early LPC in Slovakia was done by Pavúk (1962). He divided finds from the sites in western Slovakia into two stages. The first stage was further divided into two phases: Ia and Ib. The first one was characterized by the material from Milanovce and Hurbanovo, and the second phase represented transition between the sta- 


\begin{tabular}{|c|c|c|c|c|c|}
\hline \multirow{2}{*}{ BC } & \multicolumn{3}{|c|}{ Eastern Slovakia } & \multirow{2}{*}{\multicolumn{2}{|c|}{ Western Slovakia }} \\
\hline & Eastern Slovak Lowland & Košice Basin & & & \\
\hline 5300 & Early Raškovce & Tiszadob & Late ELPC & Late LPC & \\
\hline & Kopčany & Barca III & \multirow{3}{*}{ Early ELPC } & $\begin{array}{c}\text { Post-Bíña phase } \\
\text { (= Milanovce phase) }\end{array}$ & \multirow{3}{*}{ Early LPC } \\
\hline & proto-Kopčany phase & Košice-Červený rak & & Bíňa phase & \\
\hline 5500 & Moravany, Slavkovce & & & $\begin{array}{c}\text { Pre-Bíña phase } \\
\text { (=Nitra and Hurbanovo } \\
\text { phases) }\end{array}$ & \\
\hline
\end{tabular}

Tab. 1. Chronological table of Early LPC/ELPC in Slovakia (remodelled after Kalicki et al. 2005).

ges (Pavík 1962.17). After the source fund had been extended, two more phases were added to the division (Pavúk 1980.8-10, 44-45), while the author himself emphasized that the classification did not present final knowledge of the development of the Early LPC; it rather presented certain moments of development (Pavúk 1980.47). Typical decoration and surface texture of the pottery were taken as a basis for a four-phase division by the eponymous sites of Nitra, Hurbanovo, Bíña and Milanovce. In general, we can say that the Early LPC pottery contained a lot of organic admixture and thick-walled material prevailed. The Hurbanovo phase was characterized by wide cannelures which occurred also on the pottery from Bíña, while in Milanovce this element was absent. Nail scratches which were more frequent in the first three phases with dominance in Hurbanovo (nail scratches in form of a cereal ear) and in Bína were also absent in the Milanovce phase. The phase of Bíña is the best researched and documented one. Its specific shape is a biconical vessel with a slightly thickened and offset rim and a distinct bend on the belly (Pavúk 2004.16). The thickwalled pottery contains mainly semiglobular shapes decorated mostly with wide lines and engravings. The so-called Schlickbewurf (mud slip) is mentioned as an important chronological element. The latest development phase of the Early LPC, called Milanovce, is characterized by a globular vessel without a distinct bend on the belly on which three perforated vertical handles appear. The circumferential decoration is made of a wavy, often multiple grooving and a row of shallow dimples under the rims of globular vessels is a new element (Pavúk 2004.18).

Currently, a three-phase division of the Early LPC is accepted in Western Slovakia (Pavúk 2004.18; 2007;
Pavúk, Farkaš 2013).

The first one is a formative phase called Pre-Bíňa (including finds from the Nitra and Hurbanovo phases). It is followed by the Bíña phase itself with the typical biconical vessels and Schlickbewurf technique applied on thick-walled vessels. The last phase is Post-Bíña (= Milanovce phase), which - according to Pavúk (2018) - starts the expansion of the LPC all over Europe.

The ELPC has been analysed in the context of the overall evaluation of the Neolithic development in Slovakia1 (Lichardus 1970; Pavúk, Šiška 1971; 1980) or as primary study (monograph by Šiška 1989). Later the pottery of the ELPC in the Eastern Slovak Lowland (sites of Malé Raškovce, Slavkovce, Zbudza and Zalužice) was evaluated by Marián Vizdal (1997a.43-141), who also introduced a new scheme of the development of the ELPC in the Zemplín region and synchronized it with the development on the territory of north-eastern Hungary and Transcarpathian Ukraine. Other authors also dealt with the culture classification (e.g., Strobel 1997) or with selected issues of the ELPC (Lichardus 1964; 1972; Kozłowski, Nowak 2010; Nowak et al. 2010; Pavúk 1994; 2004; Piatničková 2010; 2015).

The site of Košice-Červený rak, where pottery with style and technological features analogous with the Körös culture was identified, is important for the genesis of the old Neolithic in Eastern Slovakia. The site belongs to the group of the northernmost sites representing the transitory period between the Körös culture and the Early ELPC (Kaminská et al. 2008.90), and the site qualifies as a representative of the Méhtelek Group in the territory of Slovakia (Pavúk 2004.42-43).

In the eastern territories of Slovakia the ALPC/ELPC spread to the north in its second phase. In the third and fourth phases two distinct cultural groups or units occurred, represented by the Tiszadob, Bükk and Szakálhát pottery (typical engraved ornaments), and black painted ware of the Esztár, Raškovce, Piş-

1 Earlier works dealing with the Neolithic and Aeneolithic development on the territory of present-day Slovakia originally declared that the oldest Neolithic relics in east Slovakia would be the finds from Michalovce, site 'Hradok' (features 2 and 3). Based on these, Lichardus introduced the term 'protolinear pottery' into the professional literature (Lichardus 1970.75; 1972.1-15). 
colt and Lumea Nouă Groups (further Piatničková 2015.161-165; Raczky, Anders 2003.156-158).

The ELPC development begins within so called ProtoLinear Pottery stage (the site Košice-Červený rak in the Košice Basin), followed by the Early ELPC Barca III Group (south part of the Košice Basin) and Kopčany Group (Eastern Slovak Lowland) in the western Tisza region (Šiška 1979.81-87; 1989.6269). After the Barca III and Kopčany Groups, the development continued with the evolution of the Tiszadob and Raškovce Groups, and subsequently to their phases representing the late and also the final stage of the ELPC (Šiška 1989.129-135).

The oldest Neolithic occupation on the Eastern Slovak Lowland is represented by the Proto-Kopčany phase (Vizdal 1997a.43-71). It is actually a transitional phase in the ELPC genesis, in which, besides the older traditions, the ceramic material is represented by elements that are typical throughout the further development, in the groups Kopčany and Raškovce. The following Kopčany Group is defined on the basis of finds from feature 9 at the eponymous site of Zemplínske Kopčany, and from other sites known at that time (Šiška 1982.262-263; 1989.67-74).

To other significant sites belong in the Eastern Slovak Lowland (Zemplín region) Slavkovce (Szatmár II Group) and Moravany considered as one of the earliest sites of the ELPC (e.g., Kozłowski, Nowak 2010.73-79; Kozłowski et al. 2003; Nowak et al. 2010; Vizdal 1997a.50-55, etc.).

To conclude this chapter, it is necessary to mention the absolute data of Early LPC/ELPC sites in Slovakia. Not only is there not enough such data, but the reliability of dating is also a problem, since mainly charcoal - not bones or cereals which could provide more reliable data - were used for radiocarbon measuring. In general, we only have information on the ELPC. Košice-Červený rak belongs to the oldest known sites indicating the transition from the Körös culture to the ELPC (Kaminská 2008.88). Two dates are available from the site $(6190 \pm 40 \mathrm{BP}$ and $6520 \pm 50 \mathrm{BP}$ ), and the second sample in particular presents 5563-5372 cal BC. Currently, the Neolithic settlement in Slavkovce is the oldest evidence of prehistoric farmers in the territory of eastern Slovakia (6630 90 BP; Koztowski, Nowak 2010.82). The data obtained from Zemplínske Kopčany (Pavúk, Šiš$k a$ 1980.140) suggested the occurrence of the Early ELPC around 5491-5297 cal BC. The latest data comes from the Moravany site (28 dates refer to
ELPC; Nowak et al. 2010.Tab. 7; Nowak 2015.216219, Tab. VII-1). The highest level of probability was associated with a period of $c .5500-5250 \mathrm{BC}$, while the lowest was connected with $c .5050 / 5000-4700$ $\mathrm{BC}$. In this case the foundation of the Moravany settlement was between 5600 and $5400 \mathrm{BC}$ (the fixed starting point of the settlement should be at $c .5500$ $\mathrm{BC})$ and for the end of settlement the proposed range was 5200-5150 BC (Nowak 2015.220-228). For example the established chronology of the first stage of ALPC, i.e. the Szatmár group dated to $c$. 5600 BC (Domboróczki 2009; 2010).

\section{Knowledge source}

The Early LPC in western Slovakia has been found at approx. 39 sites, and in central Slovakia there are three sites (two of them belong to the ELPC). The Early ELPC in Eastern Slovakia has been documented at least at 28 sites. The finds from western and central Slovakia mainly come from surface collections (60\%), while other finds were at rescue excavations. In the eastern part of the country, rescue excavations were carried out at more than half of the sites, while surface collections and accidental finds appear at less than a third of sites. A systematic research in eastern Slovakia was carried out at the site of Moravany (latest Kozłowski et al. 2015). In all, 70 sites with the Early LPC (ELPC) have been recorded in the territory of Slovakia (Fig. 1), occurring in 20 districts. The highest number has been recorded in the Košice District (min. 17 sites), which is followed by Michalovce District (11 sites), with both are situated in eastern Slovakia. In western Slovakia, the Early LPC is mentioned nine times in the Senec District, eight times in the Nové Zámky District and seven times in the Senica District and Nitra District. In other areas, the number decreases significantly.

The Early LPC/ELPC sites are mostly located on the Danubian and Eastern Slovak Lowlands. Settlements are situated in dry, warm climatic zones and dry chernozem soils predominate (in some areas sites are found on sandy subsoil). Overall, the most fertile sites for settlement were chosen at regular distances along larger rivers and less frequently on their tributaries, in lowlands close to water sources (Tóth et al. 2011.310-312). Localization of sites does not exceed an altitude of more than $250 \mathrm{~m}$ a.s.l. The sought natural environment was very similar in both developmental stages of the culture (Early and Late LPC), and sites were often in the same location, thus containing mixed material. 


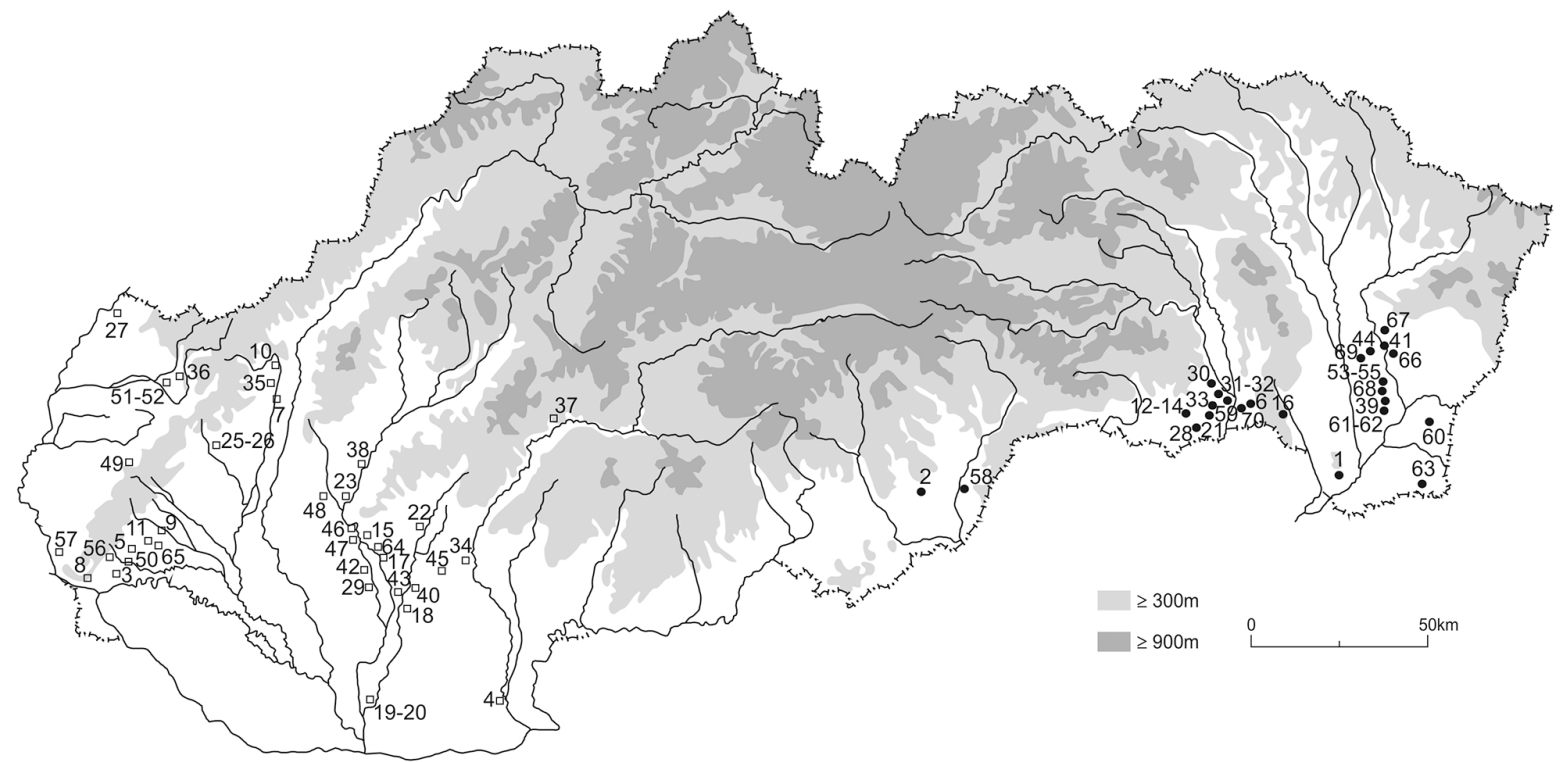

Fig. 1. Sites with finds of the Early Linear Pottery culture (squares) and Early Eastern Linear Pottery culture (circles) in Slovakia: 1 Bara; 2 Bátka; 3 Bernolákovo; 4 Bíňa; 5 Blatné (Štrky); 6 Blažice/Bohdanovce; 7 Borovce; 8 Bratislava (Mlynská ulica); 9 Cífer-Pác; 10 Čachtice; 11 Čataj; 12 Čečejovce (Gemerské); 13 Čečejovce (Balász); 14 Čečejovce (Rigó); 15 Cechynce; 16 Čel'ovce; 17 Horný Vinodol; 18 Hul; 19 Hurbanovo (Bacherov majer); 20 Hurbanovo-Bohatá; 21 Hútniky; 22 Choča; 23 Jelšovce; $24-26$ Kátlovce; 27 Kátov; 28 Komárovce; 29 Komjatice; 30 Košice (Galgovec); 31-32 Košice-Barca; 33 Košice-Šaca; 34 Kozárovce; 35 Krakovany; 36 Kunov; 37 Ladomerská Vieska; 38 Ludanice; 39 Malé Raškovce; 40 Maňa; 41 Milanovce (Vel'ký Kýr); 43 Mojzesovo; 44 Moravany (Stredné Pole); 45 Nevidzany; 46 Nitra; 47 Nitra-Dolné Krškany; 48 Nové Sady; 49 Plavecké Pohradie; 50 Senec; 51-52 Senica - Sotina; 53 Slavkovce (Hruštiny); 54 Slavkovce (Pánska Pažit'); 55 Slavkovce; 56 Slovenský Grob; 57 Stupava; 58 Tornal'a (Šafárikovo); 59 Valaliky; 60 Vel'ké Kapušany; 61-62 Vel'ké Raškovce; 63 Vel'ké Trakany; 64 Vel'ký Cetín; 65 Vel'ký Grob; 66 Zalužice (Malé Zalužice); 67 Zbudza; 68 Zemplínske Kopčany; 69 Žbince; 70 Žd'aňa.

All documented sites of the Early LPC/ELPC in Slovakia are settlements. Burials were only documented in the western part of Slovakia in three cases, however they were polycultural sites also settled in the Late LPC and even later. A child skeleton burial was discovered in feature 114/86 in Bratislava, Mlynská ulica Street (Egyházy-Jurovská, Farkaš 1987. 41). Two other skeleton burials of children were documented in Čataj (Pavúk 1976.178) and three crouched burials are mentioned in Bíña (Toč $\imath 1970$. 26-27). All of them represent burials at settlements. Besides, an accidental find of a skull and several bones discovered together with typical Early LPC pottery came from a private estate in Maňa, where they were discovered by the owner during the digging of pits (Samuel 2001.172). It is possible that an unrecognized grave find was found in Stupava (Farkaš 2012.7-12), where an assemblage containing pottery (two vessels, sherds, adze, sandstone plate) was found by accident during construction work for a family house. The surface collection in Bátka in central Slovakia brought - besides fragments of the Early ELPC pottery - fragments of a human skull (Kovács 1982.160). The finds suggest the possible presence of burials. Nevertheless, there has been no investigation at the site so far. The research of the Early ELPC site in Zalužice in eastern Slovakia in the years 1991-1995 was enabled by low water levels in the Zemplínska Šírava water reservoir. An crouching adult individual was found at a depth of $0.55 \mathrm{~m}$ under thick daub layer (floor?) in feature 1/ 91, belonging to the Kopčany Group (Vizdal 2005. 173).

Immovable archaeological sources in the form of dwellings, settlement features (storage or waste pits, clay pits) post-holes etc. from the Early LPC are rare. Complexes of features and post-holes at the SenicaSotina site were interpreted as possible remnants of an Early LPC house oriented NNE - SSW (Fig. 2). There, a sunken outdoor oven was also documented (Farkaš 2009.62). A semi-sunken pithouse of a rectangular shape from the Early ELPC is mentioned from Zbudza (Vizdal 1986.236). Feature 3/94 (4.4m $\mathrm{x} 2.5 \mathrm{~m})$ with an uneven bottom $(0.15-0.7 \mathrm{~m}$ deep) and with pole pits from the site of Zalužice is also considered to be a semi-sunken pithouse (Vizdal 1996.186-187). Nevertheless, it is not clear in either of the features if they had a residential function. The occurrence of possible hearths is interesting as well, 
since there are mentions of orange soil with charcoal and traces of burning at the Early LPC site of Cífer-Pác (Kolnik 1980a.143) and three Early ELPC sites - Moravany (Kaminská et al. 2004.95; Nowak 2015.45, 61, Fig. III-G), Košice-Barca (Bánesz, Lichardus 1969.291; Šiška 1989.153) and Čečejovce (Šiška 1980.205). A separate oven situated near sunken features is also documented by destroyed earth remains at the settlement with protolinear pottery in Košice-Červený rak (Šiška 1989.49; Kaminská et al. 2008.83-84).

The presence of various settlement features (only rarely characterized as storage pits or clay pits) was identified at least on half of the sites (altogether 131 features). The shapes of the features are mostly described as irregular or regularly oval, irregularly circular and trapeziums. As far as their sizes are concerned, we can see great variance. The average size of the features reached approx. $2-3 \times 1-2 \mathrm{~m}$ and they were $0.8-1 \mathrm{~m}$ deep. The largest features within the Early ELPC include feature 3/95 from Slavkovce (length 9m, depth 1.6-2m; Vizdal 1996.187-188), feature 3 in Košice-Barca III $(3.6$ x $4.55 \mathrm{~m}$, depth $0.3 \mathrm{~m}$; Šiška 1989.152-154), feature 3/85 in Čel'ovce (length $4.8 \mathrm{~m}$; depth $c .1 \mathrm{~m}$; Vizdal 1986.243), and feature 9 in Zemplínske Kopčany (10.4 x 2-2.5m, depth 0.6m; Šiška 1989.172). In Moravany there are

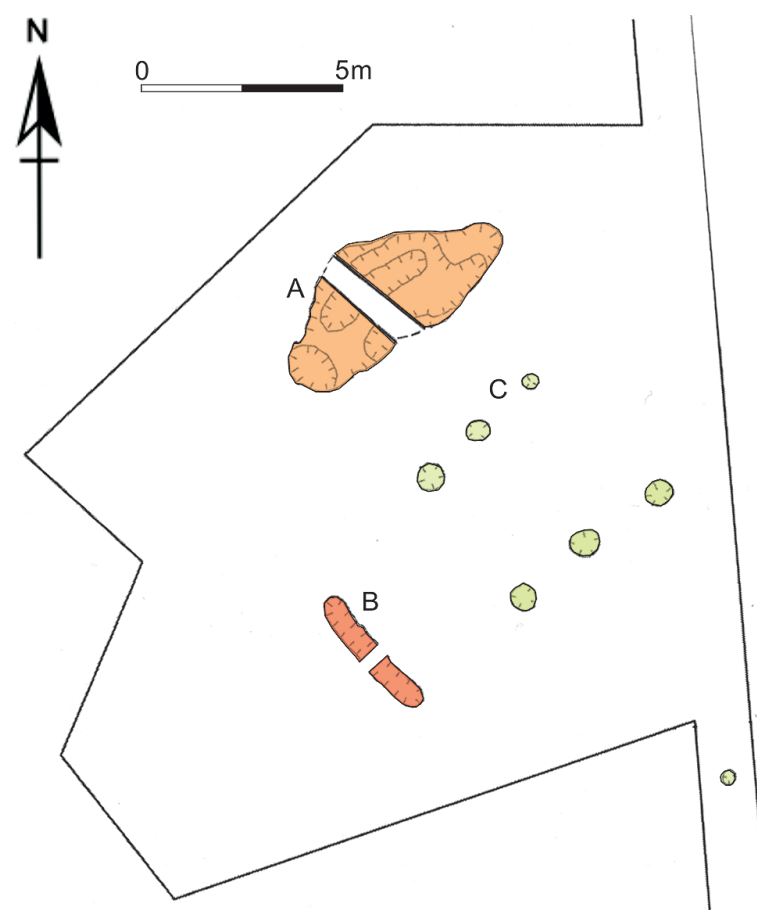

Fig. 2. Senica-Sotina site. Documented part of a dwelling with postholes (C) and surrounding features (Afeature 2/06, B feature 6/06) of the Early Linear Pottery culture in Western Slovakia (modified after Farkaš 2008.207, obr. 37.1). five features with exceptionally large dimensions: 1/98, 2/99, 3/01, 10/01 (with hearth), 1/06 (Nowak et al. 2015.43, Figs. III-3; III-4; III-5; III-6, III-7; Fig. III-8). Their plans can roughly be described as irregular ovals or trapeziums, and their dimensions vary from 7 to $10 \mathrm{~m}$ and from 4 to $5 \mathrm{~m}$ along the longer and shorter axes, respectively. In cross-section, these features can be described as hollow-shaped. Their bottoms reached $c .0 .95-1 \mathrm{~m}$ below the ground, as much as $1.7 \mathrm{~m}$ in the case of feature $1 / 06$. As for the function of the features found in Moravany, the most obvious interpretations are workshops processing obsidian and other lithic raw materials. This seems particularly likely in the case of features $1 / 98$ and 2/99 (Nowak et al. 2015.61).

In the western part of the country, the largest features of the Early LPC include feature 1/86 in Bernolákovo (2.1 x 4.8m, depth 2,48m; Farkaš 1987. 42), feature 76 in Hurbanovo-Bohatá $(6 \times 7 \mathrm{~m}$, depth 0.4-0.8m; Březinová, Pažinová 2011.26), feature 300 with oven in Cífer-Pác $(4.2 \times 2.2 \mathrm{~m}$, depth $0,9 \mathrm{~m}$; Kolnik 1980a.143) and feature 14 in Milanovce (3.3 x 2.6m, depth 1.3m; Pavúk 1980.27, 11).

It is clear by the amount of finding types documented at Early LPC/ELPC sites that there was pottery the main indicator of cultural classification - present at each of them. Chipped stone industry occurred at 21 sites, ground stones and polished products were found at 17 sites. Animal bones are reliably present at 11 sites - processed bones or bone industry were present at four sites. Miniature items are mentioned 13 times and daub is only mentioned at eight sites.

\section{Material culture}

\section{Pottery}

Recently the pottery (forms, ornamental techniques) from the Early ELPC site Moravany (Vizdal et al. 2015.85-92, 94-126, Tab. IV-7) was thoroughly analysed and evaluated, while the typological development of Early ELPC pottery in the Eastern Slovak Lowland (analysed assemblages from Moravany, Malé Raškovce, Zálužice, Slavkovce, Zbudza) was also reviewed and interpreted (Vizdal 1997a; Vizdal et al. 2015.90-94). It was proposed that the stylistictypological categories such as proto-Kopčany, Kopčany, Raškovce, etc., should tentatively be seen as pottery styles (fashions), they should not be automatically taken as successive phases of ELPC development in the Eastern Slovak Lowland. To the basic pottery forms of the ELPC belong: pots (barrel-shaped and conical pots), bowls (conical bowls, deep bul- 
bous bowls, low-thick-walled bowls/ pans), plates, pedestalled vessels/ bowls, cups and small beakers, vessels with neck, storage vessels ( $\mathrm{Viz}$ dal et al. 2015.86-88).

The published pottery represents a collection of 474 fragments in the western part of Slovakia from approx. 40 Early LPC sites, from which we could typologically classify 181 finds. This collection was divided into seven basic vessel types (or in more detail identified sub-types). Biconical vessels ( 72 specimens) were the most frequent in the collection, followed by semiglobular vessels (31 specimens). The third group - globular vessels (barrel-shaped pots) - contained 28 specimens and the richly represented pottery forms also included bowls (23 specimens). Other forms were less frequent - vessels on pedestals (14 specimens), pot-like vessels (five specimens), and vessels with neck (eight specimens).

Division of the sites according to their location within Slovakia shows differences in the occurrence of the types of finds. We do not come across all types present in the western part of Slovakia at the sites in Eastern Slovakia, and vice versa. Biconical vessels (Fig. 3) are a good example; they are completely absent in Eastern Slovakia. Vessels/bowls on pedestals are recorded in the eastern as well as western part of the territory, although tall hollow pedestals are typical of the western territory. As for various bowls, their occurrence is mostly evenly distributed. Although, for example, tall bowls are more common in the Early LPC, bowls with low thick almost vertical profiles of walls (pans) and plates are recorded only in the Early ELPC. Vessels with neck and pots (semiglobular and barrel-shaped) are represented in both territories (Fig. 4).

\section{Pottery decoration}

Statistical evaluation of the share of ornamented vessels in total pottery production encounters problems posed by huge differences in its representation at particular locations and even features. This can be
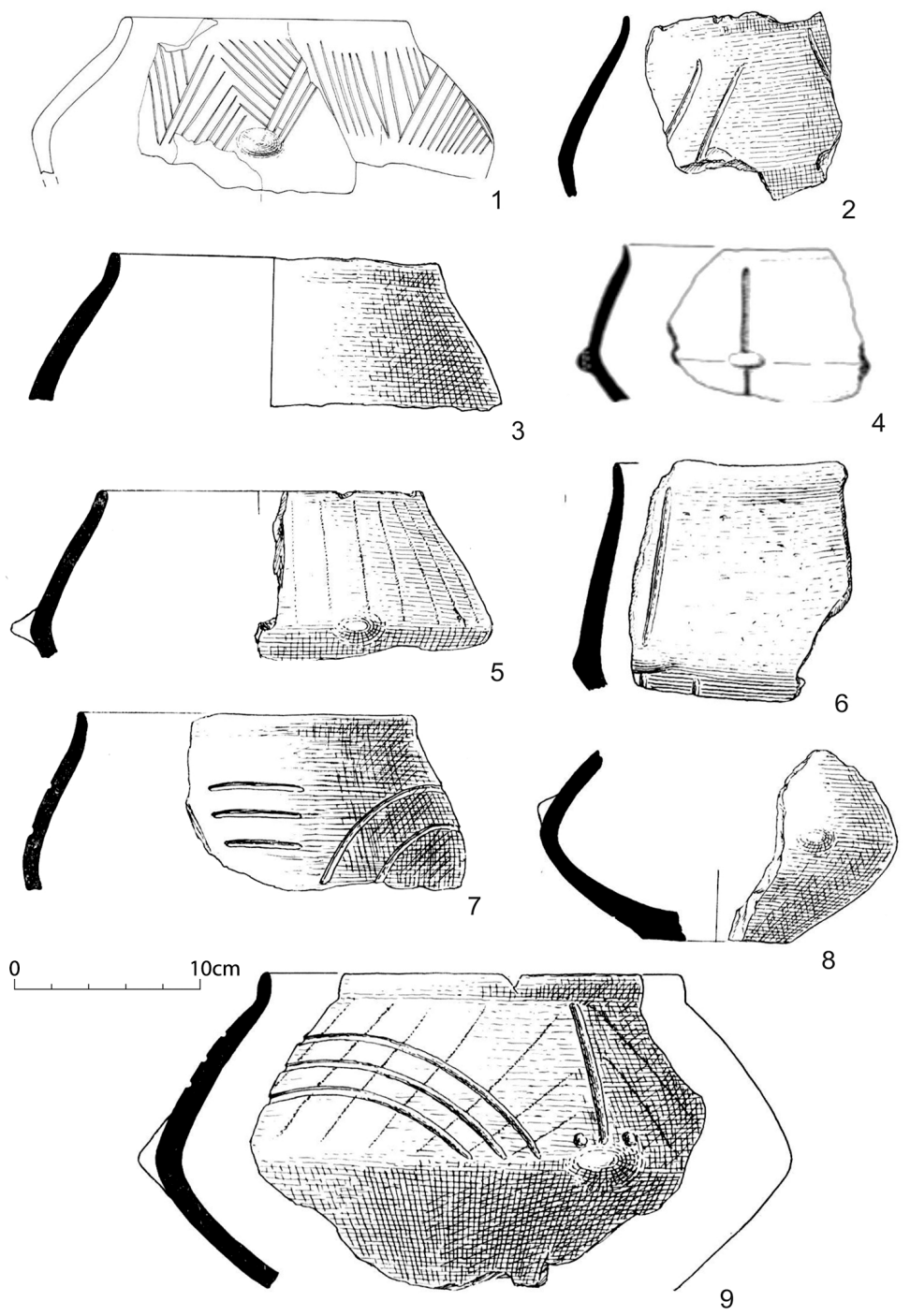

8

Fig. 3. Biconical vessels of the Early Linear Pottery culture in Western Slovakia. 1 Hurbanovo-Bohatá (after Březinová, Pažinová 2011. 234, Tab. XXXII); 2 Bíña (after Pavúk 1980.20, Abb. 7.12); 3 Bíña kaš 2013.219, Abb. 4.7); 5 Bína (after Pavúk 1980.19, Abb. 6.1); 6 Nitra (after Pavúk 1980.17, Abb. 4.2); 7 Bína (after Pavúk 1980.19, Abb. 6.3); 8 Hurbanovo (after Pavúk 1980.36, Abb. 17.2); 9 Bína (after Pavúk 1980.19, Abb. 5.2).

demonstrated by an example of sites from the Eastern Slovak Lowland. In Moravany, the share of ornamented pottery in features is less than $6 \%$. Values higher than $25 \%$ were recorded in most of the features in Zalužice, while pottery from feature1/ 1988 in Malé Raškovice consisted as much as $42.9 \%$ of decorated sherds (Vizdal 1997a; 1997b).

For the purpose of this article we analysed in terms of decoration 873 published fragments from 53 sites (36 Early LPC sites and 17 Early ELPC sites), except from the settlement at Moravany, whose ceramic material (6705 fragments altogether, various kinds of decoration identified on the surfaces of 356 
fragments $-5.3 \%$ ) was recently analysed (Vizdal et al. 2015.113).

Engraved decoration was applied on almost half of the analysed pottery (47\%). Where the documentation of the material allowed, it was possible to also identify fine (thick and thin) engraved decoration more in detail (4\%) and decoration in the form of grooving (3\%). Impressed decoration included short incised lines (4\%), pinching (3\%), impressed dimples - finger-tipped hollows (3\%), and - in two cases in the Early LPC also circular stamps.

Painted decoration was very rare and occurred exclusively in the ELPC in Eastern Slovakia. It used
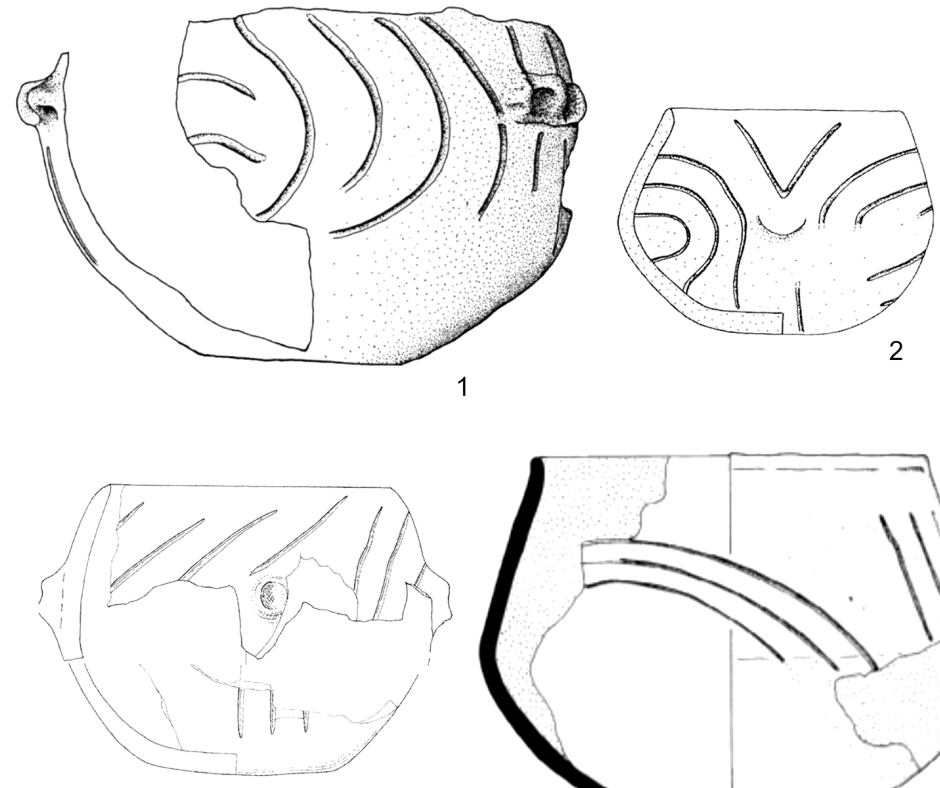

3
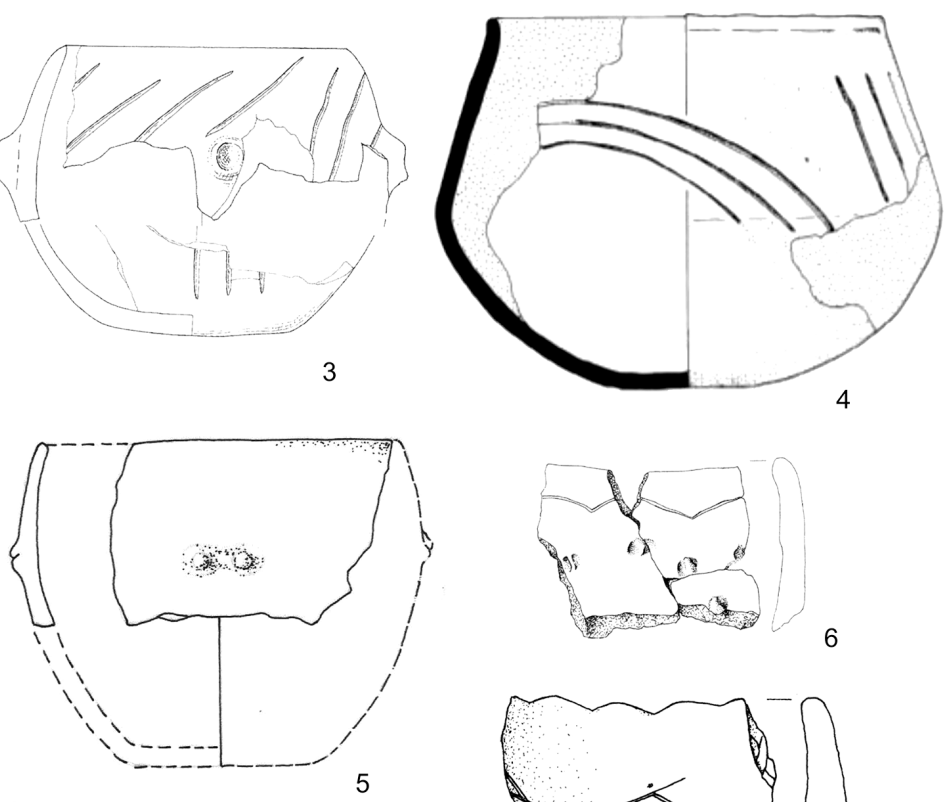

0 $10 \mathrm{~cm}$
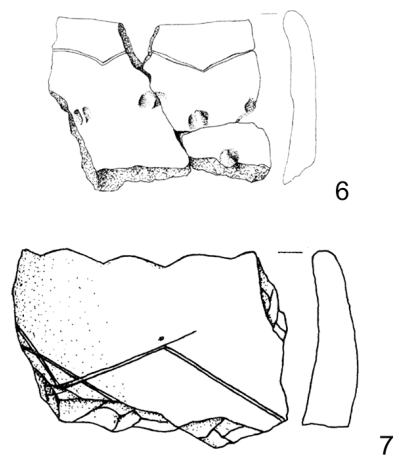

Fig. 4. Globular (barrel-shaped) vessels of the Early Linear Pottery Culture (1-4) and Early Eastern Linear Pottery Culture (5-7). 1 Maňa (after Samuel 2001.297, obr. 104); 2 Senica-Sotina (Farkaš 2008.207, obr. 37.3); 3 Hurbanovo-Bohatá (after Březinová, Pažinová 2011.256, Tab. LIV.2); 4 Bernolákovo (after Pavúk, Farkaš 2013.219, Abb. 4.4); 5 Moravany (after Vizdal et al. 2015.130, Pl. IV-4.6); 6 Zbudza (after Vizdal 1986.342, obr. 109.2); 7 Čel'ovce (after Vizdal 1986.361, obr. 131.2). only black paint (5\%), uniquely combined with engraved decoration (Slavkovce 0.6\%; Malé Raškovce $3.97 \%$ ). The diversity of ornamental motifs made by black painting or its combination with engraving is best illustrated by feature 1/1988 from Malé Raškovall the sherds - $45 \%$ within ornamented artefacts Appliqué (plastic) decoration in the form of knobs (breast-shaped, cylindrical, flat circular, tongue-shaped, etc.) which were mainly functional (of practical importance) were present on $16 \%$ of the pottery collection. Only on a small number of fragments $(5 \%)$ were combinations of a knob and ornamentation in the form of thick engraving, scratches and hollows documented. Appliqué (plastic) bands (strips) and cordons were present on $3-4 \%$ of pottery. The collection also contained very rare handles.

\section{Small clay artefacts (Fig. 5)}

First in this category, we must mention anthropomorphic figurines, including examples applied on vessels. Their presence was recorded in the Early LPC at five sites: Čataj (Pavúk 1970.31, Tab. VII.3a, b; 1976), Milanovce (Pavúk 1980.10), Vel'ký Grob (Točlk 1970.31; Pavúk 1970.31, Tab. VII.2), Vel'ké Trakany (Šiška 1989. 170), Cífer-Pác (Kolník 1978.129, obr. 70.1; 1980a.143). One exemplar was discovered in Central Slovakia in Tornal'a (Kovács 1984.5$6)$ as well as in the east in KošiceBarca III (Šiška 1989.154) and in Zemplínske Kopčany (Šiška 1989. 174-175). We must not forget the appliqué anthropomorphic scenes on a storage vessel from the protoLinear site of Košice-Červený rak (Kaminská 2008.86, Fig. 7, 8; Beljak Pažinová 2018.15).

Other clay finds include various pendants and bracelets known from the Early ELPC. They occurred in Košice, where the inventory was complemented with clay pearls (Kaminská 1998.94). In Zbudza, the most notable finds are a necklace comprising 24 beads, nine tooth-shaped and four 
fang-shaped pendants. Fragments of bracelets discovered at this site were perforated, which suggests their possible use in a necklace (Vizdal 1986.238). Bracelets were recorded in Valaliky as well, where a fragment of a horn-shaped clay artefact also comes from (Šiška 1989.168). Besides the presence of clay rings, pendants also occur in Vel'ké Trakany (Šiška 1989.170). We can also see various types of pendants in Čel'ovce (Vizdal 1986.241) and Zemplínske Kopčany (Šiška 1989.174-175, Pl. 13.12). A number of almost identical specimens of long, longitudinally drilled cylindrical pendants were found in Zalužice (Vizdal 1997b.Pl. IV-49.6) and Moravany (Vizdal et al. 2015.88).

Types of pottery products which suggest the presence of textile production and weaver's equipment are loom weights and spindle whorls. They were found at Early ELPC sites in Košice (Kaminská 1998. 94) and Zbudza (Vizdal 1986.238) and at Early LPC site in Bíña (Pavúk 1980.10).
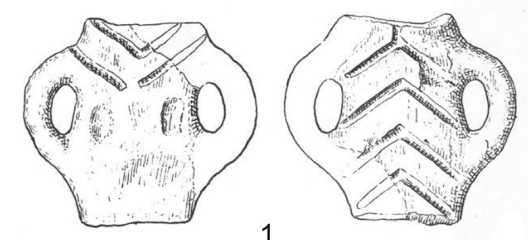
$5 \mathrm{~cm}$
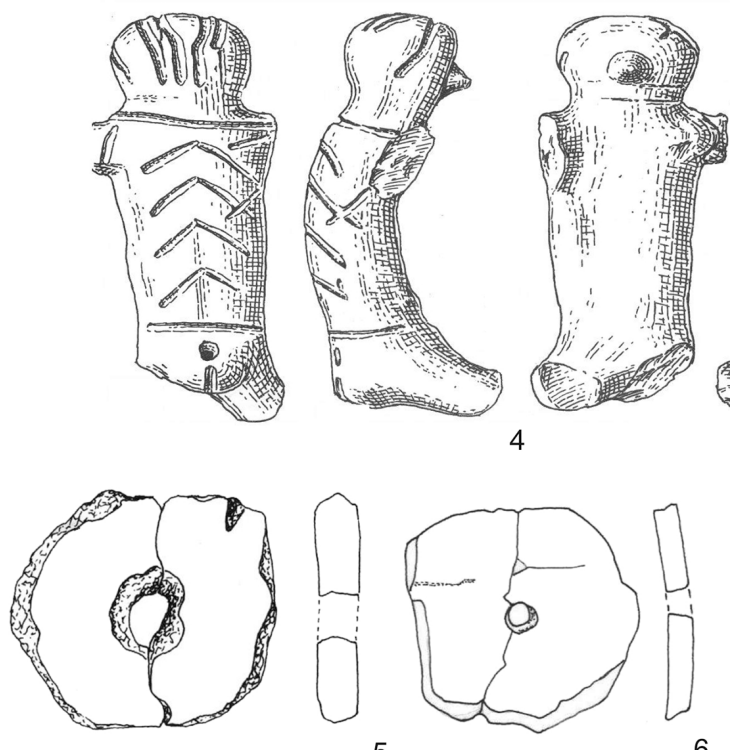

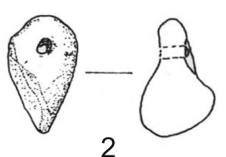

2

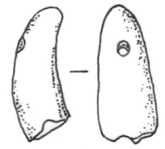

3
From the Early ELPC site Moravany a total of 5142 chipped stone artefacts have been investigated. Approximately one third of the artefacts were blades and flakes, tools were about $10 \%$, chips between 20 and 30\%, and cores were no more than 5\% (Kaczanowska et al. 2015). These finds were also quantitatively compared with other related sites (Slavkovce, Zbudza, Zalužice, Zemplínske Kopčany) in the vicinity (Nowak et al. 2010.Tabs. 1, 2). The distinctive dominance of obsidian is clear (over $80 \%$ ), followed by limnoquartzites, radiolarites and hornstone. Sites of the Early ELPC in the Eastern Slovak Lowland represent three types of quantitative structure of assemblages: Type 1 (blades with lateral retouch, retouched flakes, end-scrapers, trapezes and other microliths) in this group belong Moravany, younger assemblages from Zalužice and Kopčany; Type 2 (retouched flakes, retouched blades, end-scrapers, trapezes and other microlithic forms) - represented by finds from Slavkovce; Type 3 (retouched blades, endscrapers, retouched flakes, trapezes and other microlithic forms) - occurs at Zbudza and in the older phase of the settlement at Zalužice (Kaczanowska et al. 2015.173). At Moravany blades with lateral retouch predominate, which is also typical for other sites of the ELPC in the Eastern Slovak Lowland (Slavkovce, Zbudza, Zalužice, Kopčany). On the other hand, in the Košice Basin at the site of Čečejovce (Kozłowski 1989) a somewhat higher proportion of endscrapers than other forms with late-
Fig. 5. Small clay artefacts. Anthropomorphic applied figurines of the Early Linear Pottery culture: 1 Cífer Pác (after Kolník 1980b. 296, obr. 54.1); 4 Cífer Pác (after Kolník 1980a.337, obr. 73.1). Pendants of the Early Eastern Linear Pottery culture: 2 Zbudza (after Vizdal 1986.345, obr. 112.6); 3 Moravany (after Vizdal et al. 2015.140, Pl. IV-14.4); 5 Zbudza (after Vizdal 1986.345, obr. 112.5); 6 Moravany (after Vizdal et al. 2015.140, Pl. IV-14.13); 7 Zemplínske Kopčany (after Šiška 1989.Tab. 11.10). 
ral retouch was registered. Interesting is the discovery of a depot of unworked obsidian concretions (34 concretions that, together, weigh $13.5 \mathrm{~kg}$ ) in feature F/1988 in the Early ELPC site Slavkovce, while the total proportion of obsidian at this site is 96.0\% (Vizdal 1990.170; Kaczanowska, Kozłowski 1997). We should also mention the unusual discovery of a notched drill from the Čečejovce site which was found during surface collection (Kaminská 1982. 142). Other finds of chipped stone industry also appeared during surface collections at Early ELPC sites in Bara (Šiška 1989), Čel'ovce (Vizdal 1986.241), Košice-Galgovec (Budinsky-Krička 1976.46-54), Košice-Barca (Bánesz, Lichardus 1969), Vel'ké Raškovce (Šiška 1989; Bánesz 1981.23-26) and Vel'ké Trakany (Šiška 1989.170). However, their exact number or raw material composition is not specified.

The total minimum number of chipped stone industry finds of the Early LPC in the territory of Western Slovakia is 50. Exact amount of finds is mentioned in Bernolákovo (43 specimens; Pavúk, Farkaš 2013), Borovce (four flakes; Staššiková-Štukovská 1988.175) and Senec (one blade, two flakes; Far$k a s ̌ 1995)$. Certain number of chipped industry without further data comes from Bína (Pavúk 1980), Blatné (Pavúk 1978.192; 1988.5-8), Bratislava Mlynská ulica Street (Egyházy-Jurovská, Farkaš 1987.41), Kátov (Drahošová 1987.40), Mojzesovo (Ruttkay 1997.140) and Senica-Sotina (Farkaš 2008. 57; 2009.69). Among raw materials, obsidian prevailed (over $80 \%$ ).

\section{Ground and polished stones/artefacts}

The occurrence of ground and polished stones at Early LPC/ELPC sites is not common. Finds ( 5 axes, 16 hammerstones, 4 pounders, 20 grinding stones fragments, 12 plaquettes or flat stones, 19 fragments of pebbles) from the Moravany site in Eastern Slovakia have been comprehensively evaluated (Kaczanowska et al. 2015.175-179, Tab. V-8). All raw materials (sandstone, chalk, quartzite, tuff, hornstone, gaize, diatomite) come from local gravels (pebbles) and/or from an area $30-50 \mathrm{~km}$ around the Moravany site (Kaczanowska et al. 2015.178).

Besides Moravany ground and polished stone artefacts were recorded in the western part of Slovakia on at least eleven sites and in the east at another five sites (Tab. 2). Most often (nine times) adzes are mentioned closely followed by axes (seven times). Less common are grinders (three pieces), grinding plates (three pieces), chip (one piece) and grinding stones (three pieces).
Except for Moravany (Kaczanowska et al. 2015. 190-196, $P l . ~ V-11-V-17)$ very few displayed specimens from the analysed period are known. We found only three pieces from the Čachtice site (Kolnik, Paulik 1959.96, Tab. I.1-3) and two from Stupava (Farkaš 2012.obr. 2: 1, 5). Finds from Hurbanovo-Bohatá have been specified and analysed (Březinová, Pažinová 2011.136-140), where grinders were made from quartz fluvial pebbles, grinding plates from phillite and grinding stones from sandstone or andesit.

\section{Osteological material and bone tools}

Animal bones occurred at only two sites of the Early ELPC - Vel'ké Raškovce (five bones including a fragment of mandible; Bánesz 1981.25) and Moravany (small bones; Kaminská 2003.68-69). Within the territory of Western Slovakia (Early LPC), animal bones were present at nine sites - Senec (Farka ̌ 1995.๑); Senica-Sotina (Farkaš 2008.57); Mojzesovo (Ruttkay 1997.140); Slovenský Grob (Marková 1988.89); Bernolákovo (Pavúk, Farkaš 2013.218); Čataj (Pavúk 1976.178); Borovce (Staššíková-Štukovská 1988.174); Hurbanovo-Bohatá (Březinová, Pažinová 2011.150-151); Bíña (Pavúk 1980.10). Identified animal bones from Borovce and Hurbanovo-Bohatá point to beef cattle, swine and goat/ sheep. Besides these species, game in the form of a deer bone occurred in Borovce. The rare representation of osteological material depends on the properties of soil at the sites, which influence the preservation of such material. For instance, in the SenicaSotina site there were rather decayed and eroded bones under the related conditions, and mainly tooth enamel was detected (Farkaš 2008.57).

Processed animal bones occurred very rarely at the sites of the Early LPC. A bone spatula was only found in feature 3 in Hurbanovo-Bohatá, where there were three features with animal bones (Březinová, Pažinová 2011.167, Tab. LXIX.12). Bone tools were more frequent in Bíña and Milanovce (Pavúk 1980. Abb. 16; Točik 1970.31). In Cífer-Pác a $7.5 \mathrm{~cm}$ long perforated bear tooth was recorded in feature 300 and a bone spatula was found in feature 360 (Kolnik 1980a.145, 333, obr. 73.2, 5).

\section{Daub}

Among the features of the Early LPC, daub was reliably detected at three sites - Hurbanovo-Bohatá (pieces of surface daub in feature 73; Březinová, Pažinová 2011.104), Senica-Sotina (with imprints of wattle construction, Farkaš 2009.62) and in Borovce (daub layer of $110 \times 90 \times 136 \mathrm{~cm}$ in feature 2; Stašš iková- 
Štukovská 1988.174). Information on four small lumps of daub without specification comes from feature 1/93 in Senec (Farkaš 1995.0).

In the Early ELPC, a higher number of daub pieces or daub in form of layers occurred in Slavkovce (Skiba et al. 1996.104-105), Čel'ovce (Vizdal 1986.241), Košice-Barca, Svetlá III (Bánesz, Lichardus 1969.291) and Moravany (Kaminská 2003.69; Nowak 2015.59-61, Fig. III19). On the latter site, daub appeared in a total of 16 features out of 39 , while worth noting is the presence of daub lumps bearing structural imprints in features 1/98, 3/99-2000, 9/01, 4/ 02, and 7/01 (Nowak et al. 2015.61).

\section{Paleobotanical samples and results}

In Slovakia there are only a small number of samples with finds of grown plants from the Early LPC/ELPC (for more details see Hajnalová 2007.297; 2011.142-143; Lityńska-Zajac 1997; Lityńska-Zajac et al. 2008; Moskal-del Hoyo et al. 2015). Carbonized remains come from Borovce, Moravany, Blatné and Hurbanovo-Bohatá, imprints on daub and pottery come from Nitra-Dolné Krškany, Košice-Červený rak, Moravany, Zálužice and Slavkovce. In southwestern Slovakia, we have documented einkorn wheat (Triticum monococcum), emmer (Triticum dicoccum) and spelt (Triticum cf. spelta). In Eastern Slovakia, barley (Hordeum vulgare) and pea (Pisum sativum) are added to the einkorn wheat and emmer. Although flax (Linum usitassimum) is absent among the finds, finds of spindle whorls suggest its probable production.

\section{Discussion and conclusion}

The aim of this work was to point to the condition of research into the Early LPC/ELPC in the territory of Slovakia. It was preceded by collecting and processing of sites with relevant archaeological material known from the literature. It is clear from the obtained data that the first stage of Neolithic occupation in Slovakia is not often represented. Another negative is that in most cases only brief information on the occurrence of the Early LPC/ELPC material is published without more detailed analysis, or without more specific data.

The collection of finds from the first Neolithic culture from the territory of Slovakia represents

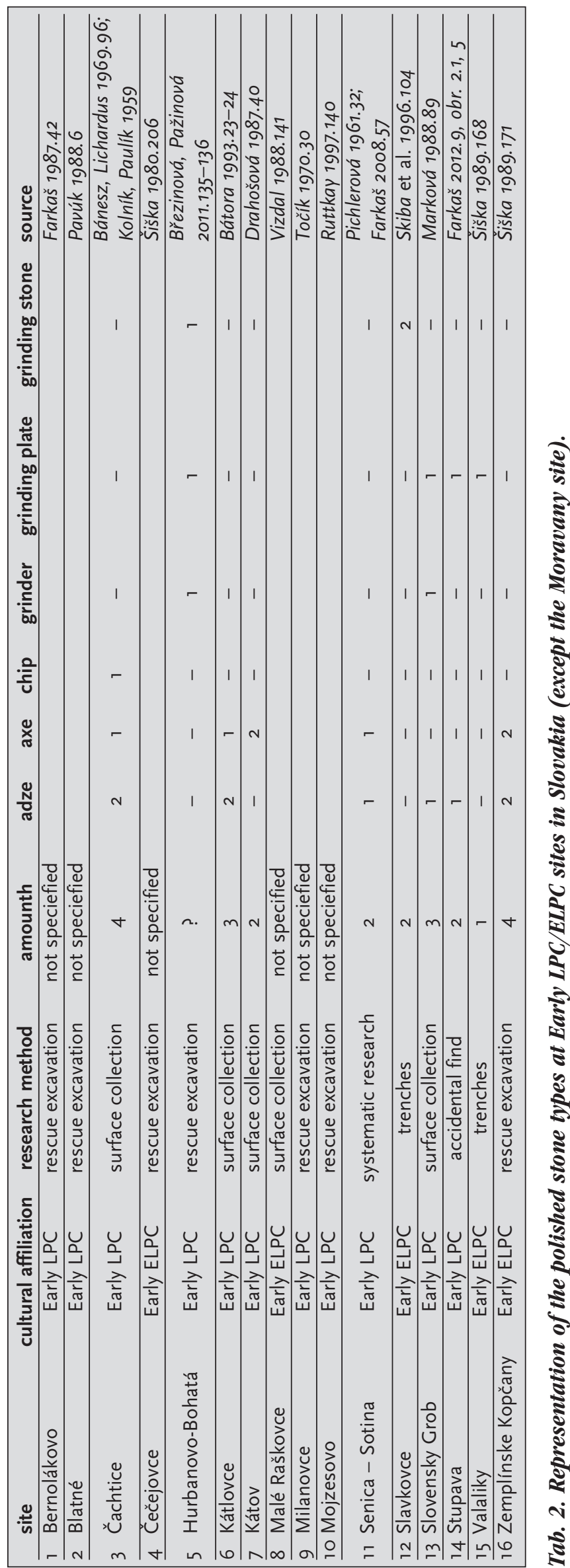


at least 70 sites; only a few of them have been studied by systematic or rescue excavations. Despite this, we cannot ignore the potential for investigation of this culture in the studied area.

The initial collection which we worked with is not ideal. Part of the material was obtained during surface collections and surveys. However, we must also emphasize that most sites are polycultural, with younger material prevailing. The sites of Malé Raškovce (Vizdal 1988.140-141), Blatné (Pavúk 1988. 6) and Mojzesovo (Ruttkay 1970.140) are good evidence of the importance of surface collections from the aspect of the investigation's further potential. Nevertheless, the number of identified features of the Early LPC/ELPC within the subsequent research was small in comparison with other periods. In the eastern part of Slovakia only three sites (Zalužice, Moravany, Zemplínske Kopčany) and in the western part five sites (Cífer-Pác, Senec-Blatné, Čataj, Senica, Hurbanovo-Bohatá) were investigated to a slightly greater extent, but even there the excavations mostly covered only a small part of the estimated total area.

The collecting and processing of the Early LPC/ELPC finds from Slovakia has resulted in a collection containing various settlement features (77\%), hearths and ovens $(8 \%)$, pole pits $(6 \%)$, dwellings $(5 \%)$, clay pits (4\%) among immovable finds. As for movable finds (besides pottery which was present at all sites), chipped stone industry (39\%), ground and polished stone industry (22\%), and animal bones (19\%) were predominant. Less than $15 \%$ of finds were small clay artefacts, daub, and bone industry.

From the material culture we first focused on pottery. The remarkable absence of biconical vessels and vessels/bowls on tall pedestals in the eastern part of the country cannot be ignored. Globular (barrel-shaped) and semiglobular vessels/pots, just like bowls, are represented in almost identical numbers in the Early LPC and ELPC collections. We must also take the following into consideration - only a small collection of Early LPC finds was used for typology and compared with recently processed Early ELPC pottery (Vizdal 1997a; Vizdal et al. 2015). This corresponds with the information value of the finds presented in the article. The pottery material was not processed only on the basis of forms but also by decoration. Pottery decoration points to frequent application of mainly engraved lines on almost half of decorated fragments. Impressed decoration was less frequent (13\%). Painting (black paint; combination of painting and engraved lines) had a 5\% share in the collection and occurred only in the eastern part of Slovakia. Appliqué (plastic) elements such as knobs, lugs, bands, cordons had an almost $25 \%$ share. In some cases perforations on the vessel bodies also occurred.

After pottery, chipped stone industry was the second most frequently represented group of finds, with occurrence in the cadastral areas of 21 villages. As for raw materials, obsidian was most often used (with the related analyses better known from Early ELPC sites in the Eastern Slovak Lowland), while the range of finds included end-scrapers, retouched blades, flakes, cores and - rarely - lumps.

Polished stones and ground stones were mentioned rarely (only at 17 sites altogether), and their exact numbers from the sites are unknown. Mainly adzes and axes were reported. Animal bones and bone industry, like small clay artefacts, were only insignificantly represented. However, we must point to the occurrence of anthropomorphic figurines at a minimum of eight sites. Discovered pieces of daub are also reported from eight sites, but their occurrence specifically at the sites of Senica (Western Slovakia) and Moravany (Eastern Slovakia) is important. Twig impressions on daub lumps suggesting timber-framed buildings have been found at these sites.

The presence of dwellings at the Early LPC settlements in Slovakia is minimal. The low number of identified houses is undoubtedly associated with the low amount of systematic research or with the rescue excavations carried out over only small areas. Analogous sites in the neighbouring countries, e.g., in Austria Brunn am Gebirge II (Lenneis 2004; Stadler 2005), Mold bei Horn (Lenneis 2003; Hofmann, Lenneis 2017), Rosenburg im Kamptal (Lenneis 2009), Neckenmarkt und Strögen (Lenneis 2001); Vedrovice-Za dvorem (Podborský et al. 2002), Popüvky (Bálek 2002) and Brno-Ivanovice (Čižmár 1998) in Moravia; or Szentgyörgyvölgy-Pityerdomb (Bánffy 2004; 2005; Bánffy, Réti 2008) and Balatonszárszó-Kis-Erdei düló (Oross 2010) in central and southern Transdanubia and Dunakeszi-Székesdüló (Horváth 2002; 2004) on the left bank of the Danube north from Budapest, show that detection of residential features is considerably complicated by their sparse distribution within settlements.

An important site that can bring new knowledge about the settlements of the Early LPC culture in Western Slovakia (Zahorie region) is Senica-Sotina 
(hung. Szotinafalva), where a part of a house ground plan was identified (Fig. 2; Farkaš 2009.62). Its dimensions and characteristics (outer pits, external hearth, orientation) are comparable to residential buildings (two houses with dimensions of 7-8.5 $\mathrm{m} \mathrm{x}$ 13-15m) excavated in Szentgyörgyvölgy - Pityerdomb in southern Transdanubia (Bánffy 2004.176177).

Similarly, in Eastern Slovakia (e.g., Zbudza: Vizdal 1986; 1990; Zalužice: Vizdal 1996; Moravany: Nowak et al. 2015), features whose interpretation encourages the presence of houses were uncovered. We therefore believe that it is only a matter of time before settlements (including dwelling houses) dated to Early LPC/ELPC can also be explored to an adequate extent in Slovakia.

Finally, it is necessary to mention the potential of research in to the focal culture in the territory of central Slovakia. The Ladomerská Vieska site in the Central Gran river basin, Žiar nad Hronom District, gives the impression that even at a distance of a minimum of $50 \mathrm{~km}$ from the centre of the Early LPC settlement in southwestern Slovakia, it is possible to trace the evidence of settlement from the beginning of the Neolithic period.

Similarly, in the eastern part of central Slovakia (the Gemer region), there are also a few surface collections (Bátka and Tornal'a sites) of the Early ELPC. It is therefore necessary to monitor the presence or absence of these early finds during future research in the central part of the country, which will clarify our knowledge about the first farmers in the territory of what is today Slovakia.

\section{ACKNOWLEDGEMENTS}

The writing of this paper has been supported by Grant VEGA No. 2/0018/19. This work was supported by the Slovak Research and Development Agency under the contract No. APVV-17-0063.

\section{References}

Andel K. 1955. Výsledok archeologického prieskumu na Zemplínsko - Užskej nížine v rokoch 1953/54. Vlastivedný sborník 1: 144-155.

Bálek M. 2002. Neolitické sídliště u Popůvek, okr. Brno venkov. In I. Cheben, I. Kuzma (eds.), Otázky neolitu a eneolitu našich krajín 2001. Slovenska akadémia vied. Nitra: 21-33.

Bánesz L. 1981. Prieskum Východoslovenskej nížiny. Archeologické výskumy a nálezy na Slovensku 1980: 2326.

Bánesz L., Lichardus J. 1969. Nové nálezy lineárnej keramiky v Barci pri Košiciach. Archeologické rozhledy 21: 291-300.

Bánffy E. 2004. The $6^{\text {th }}$ Millenium BC Boundary in Western Transdanubia and its Role in the Central European Neolithic Transition. The Szentgyörgyvölgy-Pityerdomb Settlement. Varia Archaeologica Hungarica 15. Archaeological Institute of the Hungarian Academy of Sciences. Budapest.

Bánffy E. 2005. The Early Neolithic Settlement at Szentgyörgyvölgy-Pityerdomb. Antaeus 28: 175-216.
Bánffy E., Oross K. 2009. Entwicklung und Dynamik der Linearbandkeramik in Transdanubien. In A. Zeeb-Lanz (ed.), Krisen - Kulturwandel - Kontinuität. Zum Ende der Bandkeramik in Mitteleuropa. Verlag Marie Leidorf GmbH. Rahden/Wesf.: 219-240.

2010. The earliest and the earlier phase of the LBK in Transdanubia. In D. Gronenborn, J. Petrasch (eds.), Die Neolithisierung Mitteleuropas. RGZM - Tagungen, Band 4. Verlag des Römisch-Germanischen Zentralmuseums. Mainz: 255-272.

Bánffy E., Réti Zs. 2008. Az ujkôkori építészet legkorábbi emlékei Zala megyében - a Szentgyörgyvölgy-Pityerdombi házak rekonstrukciója. Zalai Muzeum 17: 11-19.

Bátora J. 1976. Záchranný výskum na neolitickom sídlisku v Nevidzanoch. Archeologické výskumy a nálezy na Slovensku v roku 1975. Archeologický ústav Slovenskej akadémie vied. Nitra: 25-26.

Beljak Pažinová, N. 2018. Faces from the Past. Some Thoughts about Anthropomorphic and Zoomorphic Figurines and Images in the Neolithic Period. Studia Historica Nitriensia 22: 3-26.

https://doi.org/10.17846/SHN.2018.22.1.3-26 
Béreš J. 1996. Záchranný výskum neolitického a včasnostredovekého sídliska v Ždani. Archeologické výskumy a nálezy na Slovensku v roku 1995: 33.

Bielich M. 2004. Nové neolitické nálezy u Choče. Archeologické výskumy a nálezy na Slovensku v roku 2003: 34.

Březinová G., Pažinová N. 2011. Neolitická osada Hurbanovo - Bohatá. VEDA, vydavatel'stvo Slovenskej akadémie vied. Nitra.

Budinský-Krička V. 1947. Slovensko v mladšej dobe kamennej. Vydavatel'stvo Slovenskej akadémie vied. Bratislava.

1976. Archeologické prieskumy a nálezy na východnom Slovensku v roku 1975. Archeologické výskumy a nálezy na Slovensku v roku 1975. Archeologický ústav Slovenskej akadémie vied. Nitra: 46-54.

Čaplovič D., Gašaj D., and Olexa L. 1978. Archeologické prieskumy na stavbách socializmu na východnom Slovensku. Archeologické výskumy a nálezy na Slovensku v roku 1977. Archeologický ústav Slovenskej akadémie vied. Nitra: 62-70.

Čižmář Z. 1998. Osídlení Lysické sníženiny kultúrou s lineární keramikou. In J. Přostredník, V. Vokolek (eds.), Otázky neolitu a eneolitu našich zemí. Okresní muzeum Českého ráje Turnov a MVČ HK. Turnov-Hradec Králové: 23-46.

Drahošová V. 1987. Staršia LNK v Kátove. Archeologické výskumy a nálezy na Slovensku v roku 1986. Archeologický ústav Slovenskej akadémie vied. Nitra: 39-40.

Domboróczki L. 2009. Settlement structures of the Alföld Linear Pottery Culture (ALPC) in Heves County (northeastern Hungary): development models and historical reconstruction on micro, mezo and macro levels. In J. K. Kozłowski (ed.), Interaction Between Different Models of Neolithization North of the Central European AgroEcological Barrier. Prace Komisji Prehistorii Karpat 5. Polska Akademiai Umiejętności. Kraków: 75-127.

2010. Report on the excavation at Tiszaszőlós-Domaháza-puszta and a new model for the spread of the Körös culture. In J. K. Kozłowski, P. Raczki (eds.), Neolithization of the Carpathian Basin: Northernmost Distribution of the Starčevo/Körös Culture. Polish Academy of Arts and Sciences. Institut of Archaeological Science of the Eötvös Loránd University. Kraków-Budapest: 137-176.

Egyházy-Jurovská B., Farkaš Z. 1987. Pokračovanie výskumu v Mlynskej doline v Bratislave. Archeologické výskumy a nálezy na Slovensku v roku 1986. Archeologický ústav Slovenskej akadémie vied. Nitra: 41.
Eisner J. 1933. Slovensko v pravěku. Učená spoločnost' Šafárikova. Bratislava.

Farkaš Z. 1987. Neolitické sídlisko v Bernolákove. Archeologické výskumy a nálezy na Slovensku v roku 1986. Archeologický ústav Slovenskej akadémie vied. Nitra: 42.

1995. Neolitická osada v Senci. Zbornik Slovenského národného múzea 79: 5-22.

2008. Archeologický výskum v Senici. Archeologické výskumy a nálezy na Slovensku v roku 2006. Archeologický ústav Slovenskej akadémie vied. Nitra: 57-58.

2009. Pokračovanie archeologického výskumu v SeniciSotinej. Archeologické výskumy a nálezy na Slovensku v roku 2007. Archeologický ústav Slovenskej akadémie vied. Nitra: 62 .

2012. Nálezy kultúry l'udu so starou lineárnou keramikou zo Stupavy. Zbornik Slovenského národného múzea 106. Archeológia 22: 7-12.

Hajnalová M. 2007. Early farming in Slovakia: an archaeobotanical perspective. In S. Colledge, J. Connoly (eds.), The origins and spread of domestic plants in southwest Asia and Europe. Left Coast Press, Inc. London: 295-314.

2011. Rastlinné makrozvšyky. In G. Březinová, N. Pažinová (eds.), Neolitická osada Hurbanovo - Bohatá. VEDA, vydavatel'stvo Slovenskej akadémie vied. Nitra: $142-187$.

Hájek L. 1957. Nová skupina páskovej keramiky na východnom Slovensku. Archeologické rozhledy 9: 3-9.

Hofmann D., Lenneis E. 2017. Size matters? Exploring exceptional buildings in the central European early Neolithic. In P. Bickle, V. Cummings, D. Hofmann, and J. Pollard (eds.), The Neolithic of Europe. Papers of Honour of Alasdair Whittle. Oxbow Books. Oxford: 145-158.

Horváth A. 2002. Neolithische Funde und Befunde in der Gemarkung von Dunakeszi. Acta Achaeologica Academiae Scientiarum Hungaricae 53: 1-40.

2004. Angaben zu den Haustypen des mittleren Neolithikums in Ungarn. Antaeus 27: 87-93.

Horváthová E. 2017. Nálezy z mladšej doby kamennej z Kendíc. Archeologické výskumy a nálezy na Slovensku v roku 2012. Archeologický ústav Slovenskej akadémie vied. Nitra: 77-78.

Horváthová E., Hreha R. 2017. Prieskum a verifikácia archeologických nálezísk v oblasti Zemplína. Archeologické výskumy a nálezy na Slovensku v roku 2012. Archeologický ústav Slovenskej akadémie vied. Nitra: 79-84. 
Ivanič P. 2002. Výsledky výskumu v Kozárovciach a Čajkove v rokoch 1999 - 2001. Archeologické výskumy a nálezy na Slovensku v roku 2001. Archeologický ústav Slovenskej akadémie vied. Nitra: 79-80.

Kaczanowska M., Kaminská L., Kozłowski J. K., Nowak M., and Vizdal M. 2003. Ranoneolitická osada v Moravanoch, okr. Michalovce. Východoslovenský pravek 6: 4-63.

Kaczanowska M., Kozłowski J. K., and Wasilewski M. 2015. Chipped, ground and polished stone industries at the early Neolithic settlement of Moravany. In J. K. Kozłowski, M. Nowak, and M. Vizdal (eds.), Early farmers of the Eastern Slovak Lowland: The settlement of the Eastern Linear pottery culture at Moravany. Polska akademia umiejezności. Institut of Archaeological Science of the Eötvös Loránd University. Kraków: 163-195.

Kaminská L'. 1982. Výsledky prieskumu v okresoch Košice - vidiek a Trebišov. Archeologické výskumy a nálezy na Slovensku v roku 1981. Archeologický ústav Slovenskej akadémie vied. Nitra: 141-142.

1998. Záchranný výskum na preložke cesty v Košiciach. Archeologické výskumy a nálezy na Slovensku v roku 1997. Archeologický ústav Slovenskej akadémie vied. Nitra: 93-95.

Kaminská L', Kaczanowska M., and Kozłowski J. K. 2008. Košice - Červený rak and the Körös/Eastern Linear transition in the Hornád basin (eastern Slovakia). Přehled vyzkưmu 49: 83-91.

Kaminská L', Nowak M., and Vizdal M. 2003. Správa z archeologického výskumu v Moravanoch. Archeologické výskumy a nálezy na Slovensku v roku 2002. Archeologický ústav Slovenskej akadémie vied. Nitra: 68-69.

Kalicki T., Kaminská L'., Nowak M., and Vizdal M. 2004. Štvrtá sezóna slovensko - pol'ského výskumu neolitického sídliska v Moravanoch. Archeologické výskumy a nálezy na Slovensku v roku 2003. Archeologický ústav Slovenskej akadémie vied. Nitra: 95-96.

Kalicki T., Kozłowski J. K., Nowak M., and Vizdal M. 2005. A settlement of the Early Eastern Linear Pottery Culture at Moravany (Eastern Slovakia): palaeogeographical and archaeological perspective. In E. Gál, I. Juhász, and P. Sümegi (eds.), Environmental Archaeology in North-Eastern Hungary. Varia Archaeologica Hungarica 19. Institute of archaeology. Hungarian academy of sciences. Páskum Nyomda. Budapest: 179-198.

Kolník T. 1978. Ďalšia etapa výskumu v Cíferi-Páci. Archeologické výskumy a nálezy na Slovensku v roku 1977. Archeologický ústav Slovenskej akadémie vied. Nitra: 128-137. 1980a. Výskum v Cíferi-Páci v roku 1978. Archeologické výskumy a nálezy na Slovensku 1978. Archeologický ústav Slovenskej akadémie vied. Nitra: 142-155.

1980b. Výskum v Cíferi-Páci v roku 1979. Archeologické výskumy a nálezy na Slovensku 1979. Archeologický ústav Slovenskej akadémie vied. Nitra: 106-111.

Kolník T., Paulík J. 1959. Čachtice v praveku (súpis archeologickej zbierky v Čachticiach). Študijné Zvesti Archeologického ústavu Slovenskej akadémie vied 3: 87114.

Kovács Š. B. 1982. Nové nálezy východnej LNK v okrese Rimavská Sobota. Archeologické výskumy a nálezy na Slovensku 1981. Archeologický ústav Slovenskej akadémie vied. Nitra: 165-168.

1984. Výskumy a prieskumy Gemerského múzea v okrese Rimavská Sobota. Archeologické výskumy a nálezy na Slovensku 1983. Archeologický ústav Slovenskej akadémie vied. Nitra: 45.

Kozłowski J. K., Nowak M. 2010. From Körös/Cris to the early Eastern Linear Complex: multidirectional transitions in the north-eastern fringe of the Carpathian Basin. In J. K. Kozłowski, P. Raczky (eds.), Neolithization of the Carpathian Basin: Northernmost Distribution of the Starčevo/Körös Culture. Polska Akademia Umiejętności. Kraków- Budapest: 65-90.

Kozłowski J. K., Nowak M., and Vizdal M. 2003. A settlement of the Early Eastern Linear Culture at Moravany (Eastern Slovakia) within the context of the neolithization of the Upper Tisza Basin. In E. Jerem, P. Raczky (eds.), Morgenrot der Kulturen. Frühe Etappen der Menschheitsgeschichte in Mittel - und Südosteuropa. Festschrift für Nándor Kalicz zum 75. Geburtstag. Archaeolingua. Budapest: 127-145.

Kozłowski J. K., Nowak M., and Vizdal M. (eds.) 2015. Early farmers of the Eastern Slovak Lowland: The settlement of the Eastern Linear pottery culture at Moravany. Polska akademia umiejezności. Kraków.

Lenneis E. (ed.) 2001. Die altbandkeramischen Siedlungen von Neckenmarkt und Strögen. Das Fundgut. Studien zu Struktur und Entwicklung frühneolithischer Siedlungen im östlichen Mitteleuropa. Universitätsforschungen zur Prähistorischen Archäologie 82. Verlag Dr. Rudolf Habelt GmbH. Bonn.

2003. Ein bandkeramischer Großbau aus Mold bei Horn, Niederösterreich in seinem europäischen Kontext. In B. Asamer, W. Wohlmayr (eds.), Akten des 9. Österreichischen Archäologentages. Phoibos. Wien: 135-137. 
2004. Architecture and Settlement Structure of the Early Linear Pottery Culture in East Central Europe. In A. Lukes, M. Zvelebil (eds.), LBK Dialogues. Studies in the Formation of the Linear Pottery Culture. British Archaeological Reports IS 1304. Archaeopress. Oxford: 151-157.

2009. Rosenburg im Kamptal - Ein „Sonderplatz“ der älteren Linearbandkeramik. Universitätsforschungen zur Prähistorischen Archäologie. Verlag Dr. Rudolf Habelt $\mathrm{GmbH}$. Bonn.

2010. Zur Chronologie der älteren Linearbandkeramik in Österreich. In J. Šuteková, P. Pavúk, P. Kalábková, and B. Kovár (eds.), Panta Rhei, Studies in chronology and cultural developement of south-eastern and central Europe in earlier prehistory presented to Juraj Pavík on the occasion of his 75. Birthday. Comenius University in Bratislava and Archaeological centre, Olomouc. Bratislava: 189-200.

Lichardus J. 1964. Beitrag zur Linearbandkeramik in der Ostslowakei. Archeologické Rozhledy 16: 841-881.

1970. Neolitické kultúry na východnom Slovensku. In A. Točík (ed.), Slovensko v mladšej dobe kamennej. Vydavatel'stvo Slovenskej Akadémie Vied. Bratislava: 65-115.

1972. Zur Entstehung der Linearbandkeramik. Germania 50: 1-15.

Lityńska-Zając M. 1997. Plant impressions on daub - Slavkovce and Zalužice. In J. K. Kozłowski (ed.), The Early Linear Pottery Culture in Eastern Slovakia. Polska akademia umiejezności. Kraków: 225-258.

Lityńska-Zając M., Moskal-del Hoyo M., and Nowak M. 2008. Plant remains from Early Neolithic settlement at Moravany (Eastern Slovakia). Vegetation History and Archaeobotany 17, Supplement 1: 1-92.

https://doi.org/10.1007/s00334-008-0179-1

Marková M. 1988. Prieskum v oblasti Slovenského Grobu. Archeologické výskumy a nálezy na Slovensku 1987. Archeologický ústav Slovenskej akadémie vied. Nitra: 89.

Marton T., Oross K. 2012. Siedlungsforschung in linienbandkeramischen Fundorten in Zentral- und Südtransdanubien - Wiege, Peripherie oder beides? In R. Smolnik (ed.), Siedlungsstruktur und Kulturwandel in der Bandkeramik. Beiträge der internationalen Tagung "Neue Fragen zur Bandkeramik oder alles beim Alten?!". Leipzig, 23. Bis 24. September 2010. Landesamt für Archäologie. Dresden: 220-240.

Moskal-del Hoyo M., Lityńska-Zając M., and Badal E. 2015. Archaeobotany: Agriculture and plant exploitation in the early Neolithic settlement at Moravany. In J. K. Kozłowski, M. Nowak, and M. Vizdal (eds.), Early farmers of the Eastern Slovak Lowland: The settlement of the Eastern Linear pottery culture at Moravany. Polska akademia umiejezności. Kraków: 197-214.

Mosný P., Šš̌ka S. 1997. Ladomerská Vieska - 1. nálezisko kultúry s LNK v Žiarskej kotline. Archeologické výskumy a nálezy na Slovensku 1997. Archeologický ústav Slovenskej akadémie vied. Nitra: 120.

Nowak M., Kozłowski J. K., Kaczanowska M., Vizdal M., Kalicki T., Moskal-del Hoyo M., Budek A., Litvinyuk G., Lityńska-Zając M., Stobierskam E., and Wyszomirski P. 2010. Early Neolithic in the Upper Tisza Basin: New Data from Moravany, Eastern Slovakia. Eurasian Prehistory 7: 153213.

Nowak M. 2015. Absolute chronology of the settlement of the Eastern Linear Pottery culture at Moravany. In J. K. Kozłowski, M. Nowak, and M. Vizdal (eds.), Early farmers of the Eastern Slovak Lowland: The settlement of the Eastern Linear pottery culture at Moravany. Polska akademia umiejezności. Kraków: 215-234.

Oross K. 2010. Architecture of the Linearbandkeramik settlement at Balatonszárszó-Kis-erdei-dúlő in central Transdanubia. In D. Gheorghiu (ed.), Neolithic and Chalcolithic Archaeology in Eurasia: Building Techniques and Spatial Organisation. Proceedings of the XVth World Congress UISPP (Lisbon, 2006). Archaeopress. Oxford: 63-80.

Pavlů I. 2012. Models and scenarios of the Neolithic in Central Europe. Documenta Praehistorica 39: 95-102. https://doi.org/10.4312/dp.39.7

Pavúk J. 1962. Gliederung der Volutenkeramik in der Slowakei. Študijne Zvesti Archeologického Ústavu Slovenskej Akadémie Vied 9: 5-20.

1970. Kultúry staršieho a stredného neolitu na západnom Slovensku. In A. Točik (ed.), Slovensko v mladšej dobe kamennej. Vydavatel'stvo Slovenskej Akadémie vied. Bratislava: 20-64, 247-253.

1976. Záchranný výskum na terase autostrády v Čataji. Archeologické výskumy a nálezy na Slovensku 1975. Archeologický ústav Slovenskej akadémie vied. Nitra: 177-182.

1978. Výskum neolitického sídliska v Blatnom. Archeologické výskumy a nálezy na Slovensku 1977. Archeologický ústav Slovenskej akadémie vied. Nitra: 192-195.

1980. Ältere Linearkeramik in der Slowakei. Slovenská archeológia 28: 7-90. 
1994. Zur relativen Chronologie der älteren Linearkeramik. Nyíregyházi Jósa András Múzeum Évkönyve 36: 135-149.

2004. Stará lineárna keramika a neolitizácia strednej Európy. In M. Lutovský (ed.), Otázky neolitu a eneolitu 2003. Ústav archeologické památkové péče středních Čech. Praha: 11-28.

2007. Die Entstehung und Gliederung der neolithischen Kulturen auf dem Zentralbalkan: Fallbeispiel Gălăbnik. In H. Todorova, M. Stefanovich, and G. Ivanov (eds.), The Struma/Strymon River Valley in Prehistory. Museum of History-Kyustendil. Sofia: 165-176.

2014. Vznik kultúry s lineárnou keramikou vo svetle chronológie neolitických kultúr na Balkáne. In M. Popelka, R. Šmidtová (eds.), Neolitizace aneb setkání generací. Univerzita Karlova v Praze. Praha: 175-218.

2018. Balkán - Karpatská kotlina - Čechy: kultúrnochronologický kontext. Živá archeologie - Rekonstrukce a experiment $v$ archeologii 20: 6-14.

Pavúk J., Farkaš Z. 2013. Beitrag zur Gliederung der älteren Linearbandkeramik. In A. Anders, G. Kulcsár (eds.), Moments in Time: Papers Presented to Pál Raczky on his $60^{\text {th }}$ Birthday. Ösrégészeti Tanulmányok/Prehistoric Studies I. Eötvös Loránd University, L’Harmattan. Budapest: $213-236$.

Pavúk J., Šiška S. 1971. Neolitické a eneolitické osídlenie Slovenska. Slovenská archeológia 1971: 319-364.

1980. Návrh chronológie praveku a včasnej doby dejinnej na Slovensku. Neolit a eneolit. Slovenská archeológia 28: 137-158.

Piatničková K. 2010. Problematic of Linear Pottery in the Upper Tisza Region. In J. Šuteková, P. Pavúk, P. Kalábková and B. Kovár (eds.), Panta Rhei, Studies in chronology and cultural developement of south-eastern and central Europe in earlier prehistory presented to Juraj Pavuk on the occasion of his 75. Birthday. Comenius University in Bratislava and Archaeological centre, Olomouc. Bratislava: 323-343.

2015. The Eastern Linear Pottery Culture in the Western Tisza Region in Eastern Slovakia. The Tiszadob Group as a Base of the Bükk Culture. In C. Virag (ed.), Neolithic cultural phenomena in the upper Tisza basin. International Conference: July 10-12, 2014. Editura Muzeului Satmarean. Satu Mare: 161-184.

Podborský V. et al. 2002. Dvě pohřebiště neolitického lidu s lineární keramikou ve Vedrovicích na Moravě. Masarykova univerzita, Filozofická fakulta, Ústav archeologie a muzeologie. Brno.
Raczky P., Anders A. 2003. The internal relations of the Alföld Linear Pottery culture in Hungary and the characteristics of human representation. In E. Jerem, P. Raczky (eds.), Morgenrot der Kulturen. Frühe Etappen der Menschheitsgeschichte in Mittel- und Südosteuropa. Festschrift fur Nándor Kalicz zum 75. Geburtstag. Archaeolingua 15. Budapest: 155-182.

Ruttkay M. 1997. Záchranný výskum v Mojzesove. Archeologické výskumy a nálezy na Slovensku 1997. Archeologický ústav Slovenskej akadémie vied. Nitra: 140.

Ruttkayová J. 2004. Nádoba kultúry so staršou lineárnou keramikou z Nitry - Dolných Krškán. Archeologické výskumy a nálezy na Slovensku 2003. Archeologický ústav Slovenskej akadémie vied. Nitra: 161.

Samuel M. 2001. Nálezy z Mane. Archeologické výskumy a nálezy na Slovensku 2001. Archeologický ústav Slovenskej akadémie vied. Nitra: 171-172.

Sedlák K. 1975. Neolitické a neskorolaténske sídlisko v Krakovanoch. Archeologické výskumy a nálezy na Slovensku 1974. Archeologický ústav Slovenskej akadémie vied. Nitra: 98.

Skiba S., Nowak M., Vizdal M., Kozłowski I., and Kaczanowska M. 1996. Správa zo Slovensko-Pol'ských výskumov v Slavkovciach. Archeologické výskumy a nálezy na Slovensku 1996. Archeologický ústav Slovenskej akadémie vied. Nitra: 104.

Stadler P. 2005. Settlement of the Early Linear Ceramics Culture at Brunn am Gebirge, Wolfholz site. Documenta Praehistorica 32: 269-278.

https://doi.org/10.4312/dp.32.21

Staššiková-Štukovská D. 1988. Sídliskové nálezy a hrob z Boroviec. Študijné Zvesti Archeologického ústavu Slovenskej akadémie vied 24: 173-190.

Strobel M. 1997. Ein Beitrag zur Gliederung der östlichen Linienbandkeramik. Versuch einer Merkmalsanalyse. Saarbrücker Studien und Materialien zur Altertumskunde 4/5 (1995/1996): 9-98.

Šiška S. 1979. Počiatky neolitického osídlenia východného Slovenska. In W. Wojciechowski, B. Gediga, and L. Leciejewicz (eds.), Poczatki neolityzacji polski poludniowo - zachodniej: materialy konferencyjne. Polska Akademia Nauk. Oddział. Wroclaw: 81-92.

Šiška S. 1980. Neolitické a halštatsko-laténske sídlisko v Čečejovciach. Archeologické výskumy a nálezy na Slovensku 1979. Archeologický ústav Slovenskej akadémie vied. Nitra: 204-207. 
1981. Druhý výskum v Čečejovciach. Archeologické výskumy a nálezy na Slovensku 1980. Archeologický ústav Slovenskej akadémie vied. Nitra: 286-289.

1982. Kultur mit östlicher Linearkeramik in der Slowakei. In B. Chropovský (ed.), Siedlungen der Kultur mit Linearkeramik in Europa. Internationales Kolloquium. Nove Vozokany 17.-20. November 1981. Slovenská Akadémia vied. Nitra: 261-270.

1989. Kultúra s východnou lineárnou keramikou na Slovensku. Vydavatel'stvo Slovenskej akadémie vied. Nitra.

Točík A. 1970. Slovensko v mladšej dobe kamennej. Vydavatel'stvo Slovenskej akadémie vied. Bratislava.

1978. Záchranný výskum v Komjaticiach. Archeologické výskumy a nálezy na Slovensku 1977. Archeologický ústav Slovenskej akadémie vied. Nitra: 246-272.

Tóth P., Demján P., and Griačová K. 2011. Adaptation of settlement strategies to environmental conditions in southern Slovakia in the neolithic and eneolithic. Documenta Praehistorica 38: 307-321.

https://doi.org/10.4312/dp.38.24

Verčik M. 2002. Nový neolitický nález z Boroviec. Archeologické výskumy a nálezy na Slovensku 2002. Archeologický ústav Slovenskej akadémie vied. Nitra: 224.

Vizdal M. 1986. Výskumy a nálezy múzea v Michalovciach. Archeologické výskumy a nálezy na Slovensku 1985. Archeologický ústav Slovenskej akadémie vied. Nitra: 237238.

1988. Prieskum a záchranný výskum v Malých Raškovciach. Archeologické výskumy a nálezy na Slovensku 1985. Archeologický ústav Slovenskej akadémie vied. Nitra: 140-141.
1990. Zachranný výskum v Slavkovciach. Archeologické výskumy a nálezy na Slovensku 1985. Archeologický ústav Slovenskej akadémie vied. Nitra: 169-170.

1990. Sídlisková jama s lineárnou keramikou v Zbudzi, okres Michalovce. Historica Carpatica 21: 117-131.

1996. 5. sezóna výskumu neolitického sídliska v Zalužiciach. Archeologické výskumy a nálezy na Slovensku 1995. Archeologický ústav Slovenskej akadémie vied. Nitra: 186-187.

1997a. Pottery finds. In J. K. Kozłowski (ed.), The Early Linear Pottery Culture in Eastern Slovakia. Polska akademia umiejezności. Krakow: 43-141.

1997b. Die ältere östliche Linienbandkeramik in Male Raškovce, Bezirk Michalovce. Saarbrücker Studien und Materialien zur Altertumskunde 4-5(1995-1996): 99-142.

2005. Neolitické sídlisko v Zalužiciach a jeho význam pre poznanie genézy Kultúry s východnou lineárnou keramikou. In J. Mojdis (ed.), Zrkadlo histórie 2. Filozofická fakulta Prešovskej Univerzity v Prešove. Prešov: 167-196.

Vizdal M., Derfiňák P. 2006. Ďalšie nálezy z Vel'kého Šariša. Archeologické výskumy a nálezy na Slovensku v roku 2004. Archeologický ústav Slovenskej akadémie vied. Nitra: 213.

Vizdal J., Paulík J. 1957. Neolitické nálezy v Kopčanoch. Archeologické rozhledy 11: 785-787.

Vizdal M., Vizdal M., Vol'anská A., and Nowak M. 2015. Ceramic materials from the settlement of the Eastern Linear Pottery culture at Moravany. In J. K. Kozłowski, M. Nowak, and M. Vizdal (eds.), Early farmers of the Eastern Slovak Lowland: The settlement of the Eastern Linear pottery culture at Moravany. Polska akademia umiejezności. Kraków: 85-162.

\section{back to contents}

